ppi $201502 Z U 4645$

Esta publicación cientifica en formato digital es continuidad de la revista impresa ISSN-Versión Impresa 0798-1406 / ISSN-Versión on line 2542-3185Depósito legal pp

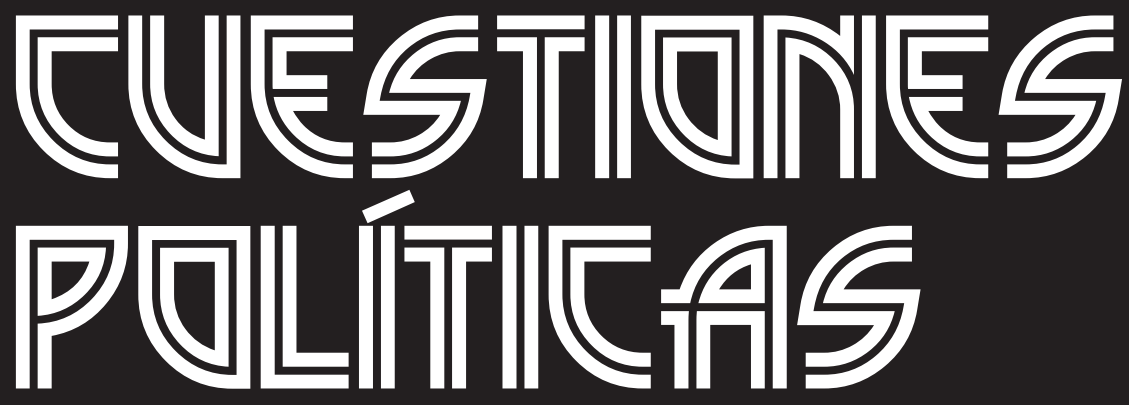

Instituto de Estudios Políticos y Derecho Público "Dr. Humberto J. La Roche' de la Facultad de Ciencias Jurídicas y Políticas de la Universidad del Zulia Maracaibo, Venezuela
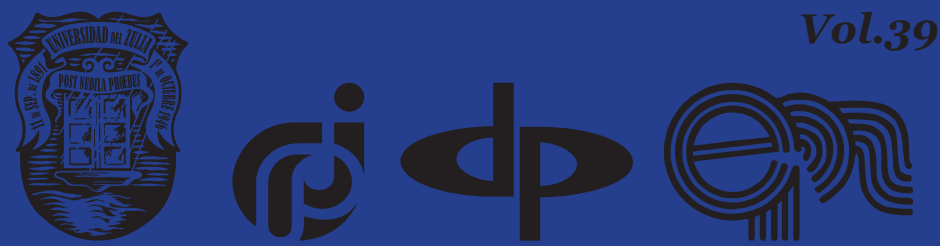


\title{
Function of Criminal Analysis in Modern Models of Police Activity
}

\author{
DOI: https://doi.org/10.46398/cuestpol.3968.26
}

\author{
Maksym V. Korniienko * \\ Valentyna $V$. Horoshko ** \\ Igor M. Gorbanov *** \\ Karen Yu. Ismailov ****
}

\begin{abstract}
The objective of the article is to conduct a study of the role of criminal analysis in modern models of police activity. To achieve this objective, several methods were used, namely: analysis of official documentation, scientific literature, logical analysis, concrete-historical, dialectic, or empirical methods. The article presents the most common classifications of police models today, as well as the interpretation of criminal analysis in them. It is concluded that a relatively new model of intelligence-led surveillance needs to be implemented in the police. Within the police model of social orientation, specific ways of solving various problems are carried out by carefully and detailed analysis of the causes of such problems, actors, and characteristics of the area, as well as the prevention of serious crimes through the approach of police work in places of concentration of minor infringements (model of "broken windows"). It was noted that Comp Stat focuses on street crime and in series with short-term responsibility for addressing new criminal challenges; for its part, the intelligence-led surveillance (ILP) model includes a long-term strategic component that can be applied to transnational organized crime
\end{abstract} operations.

Keywords: information-analytical activity; analytical theoretical work; management decision-making; law enforcement; model of police action.

* Full Doctor in Law, Head of the Department of Administrative Activity of the Police, Odessa State University of Internal Affairs, Ukraine. ORCID ID: https://orcid.org/oooo-ooo2-6420-6169. Email: korniienko2015@tanu.pro

** PhD in Law, Head of the Department of Criminology and Psychology, Odessa State University of Internal Affairs, Ukraine. ORCID ID: https://orcid.org/oooo-0oo3-1141-1975. E-mail: horoshko@ nuos.pro

*** PhD in Law, Professor at the Department of Criminology and Psychology, Odessa State University of Internal Affairs, Ukraine. ORCID ID: https://orcid.org/oooo-0002-0100-1107. Email: gor-i-gor@ uohk.com.cn

***** PhD in Law, Head of the Department of Cyber Security and Information Support, Odessa State University of Internal Affairs, Ukraine. ORCID ID: https://orcid.org/oooo-0oo1-5137-2507. Email: 0997060070@nuos.pro 


\section{Función del análisis criminal en modelos modernos de actividad policial}

\section{Resumen}

El objetivo del artículo es realizar un estudio de la función del análisis criminal en modelos modernos de actividad policial. Para lograr este objetivo, se utilizaron varios métodos, a saber: análisis de documentación oficial, literatura científica, análisis lógico, concreto-histórico, dialéctico y métodos empíricos. El artículo presenta las clasificaciones más comunes de los modelos policiales en la actualidad, así como la interpretación del análisis criminal en ellas. Se concluye que es necesario implementar en la policía un modelo relativamente nuevo de vigilancia dirigida por inteligencia. Dentro del modelo policial de orientación social, se llevan a cabo formas específicas de resolver diversos problemas mediante el análisis cuidadoso y detallado de las causas de dichos problemas, los actores y las características del área, así como la prevención de delitos graves mediante el enfoque del trabajo policial en los lugares de concentración de infracciones leves (modelo de "ventanas rotas"). Se señaló que Comp Stat se centra en la delincuencia callejera y en serie con responsabilidad a corto plazo para abordar los nuevos desafíos delictivos; por su parte, el modelo de vigilancia dirigida por inteligencia (ILP) incluye un componente estratégico a largo plazo que se puede aplicar a las operaciones contra la delincuencia organizada transnacionales.

Palabras clave: actividad de información-analítica; trabajo teórico analítico; toma de decisiones gerenciales; aplicación de la ley; modelo de actuación policial.

\section{Introduction}

Given the history of criminal analysis and the emergence of the profession of criminal analyst, which began in the 1800 , when the London City Police began to use statistics, "hot spots", "crime schemes", and from the second half of the nineteenth century the first law enforcement concept, the model of policing, the modus operandi (method of committing a crime) (Fosdick, 1916), had already begun to be separated. And later the classification of offenders and crimes was formed on its basis, policing began to acquire different models that are constantly evolving and require an extremely complex balance in the field of public safety, crime prevention, community engagement and timely response. Police models cover both functional and administrative functions, which usually include certain aspects of problem identification, information flow, and analytical work for effective modern crime control. 
Today, only with a clear strategy of functioning and development, the police will be able to proportionally repel modern challenges and threats, primarily hybrid, which are due to the influence of a complex of sociodemographic, economic, political, legal, psychological, and technological factors. Moreover, the role of analytical work of police units in combating crime is currently being strengthened, as stated in the Strategy for the Development of the System of the Ministry of Internal Affairs of Ukraine until 2020 (Order of the Cabinet of Ministers of Ukraine, 2017). Thus, in the framework of combating crime, attention was paid to the low level of use of analytical tools by police in combating crime and forecasting relevant threats, to overcome which, the same Strategy states that it is necessary to implement the concept of the Ministry of Internal Affairs based on various sources of information (Intelligence Led Policing (ILP)), comprehensive implementation of modern criminal analysis systems, including the EUROPOL methodology (Order of the Cabinet of Ministers of Ukraine, 2017).

International experience in the use of preventive measures, which is currently used by law enforcement agencies, shows that criminal analysis is a key tool for national security. The essence of criminal analysis is to identify and determine as accurately as possible the internal links between information (information, data) relating to criminal offenses, and any other data used in the interests of operational and investigative and investigative activities, their analytical support, as well as the development of tactical and strategic measures to combat crime. From a methodological point of view, criminal analysis is a set of methods used to collect, evaluate, analyze, and implement information in the investigation of criminal offenses, as well as to use them in developing tactical and strategic principles in combating crime (Korystin et al., 2016).

Today we are already observing the creation of new analytical units of the National Police of Ukraine (Criminal Analysis Department of NPU) and the gradual transition of other police units to the use of modern information-analytical software and investigative methods (SOCTA), which certainly improves the effectiveness of the activities of police bodies and units during the execution tasks for the protection of human rights and freedoms and combating crime. Thus, implementing a model of proactive activity that replaces the dominant paradigm of reactive policing. Thus, with the introduction of new modern information technologies and highly intelligent software into police activity, a new field is emerging, where the issue of ensuring human rights and freedoms in the model of Intelligence Led Policing (ILP) is not yet discussed enough at the scientific level and at the legislative level, that is why this issue becomes relevant today (Ismailov, 2019). The purpose of the article is a comprehensive analysis of the function of criminal analysis in various modern models of policing. 
Maksym V. Kornïenko, Valentyna V. Horoshko, Igor M. Gorbanov y Karen Yu. Ismailov Function of Criminal Analysis in Modern Models of Police Activity

\section{Literature Review}

Before we move on to consider the function of criminal analysis in different models of policing, let us briefly find out what scientists and practitioners invest in the concept of policing. Yes, K.S. Belskyi emphasizes that policing in a broad sense should be understood as a special type of public administration activity aimed at protecting public order, ensuring public (as well as any other) security, and related to the use of state coercion (Belskyi, 2004). According to V.M. Shadrin, policing is a special type of social, public administration activity carried out based on law and in the interests of society, aimed at protecting and maintaining public order, ensuring public safety by means of coercion (Shadrin, 2003). O.S. Pronevich proposes to consider policing as a coercive activity to restore public order and ensure the safety of citizens (Pronevich, 2009).

The Declaration on the Police (1979) adopted by the Council of Europe Assembly on 08.05.1979, states that the meaning of policing is to protect citizens and society from violence, robbery, and other socially dangerous acts, and pays special attention to the priority of in-depth training of police personnel, on social issues, democratic rights and human freedoms. As we see, all these definitions of policing are based on the general principles of protection of human rights and freedoms based on law and further in the text, but they do not contain a specific model (form) of law enforcement or several complementary law enforcement models.

Other scholars note the following, Professor A.V. Movchan in his writings analyzes the current problems of implementation in the bodies of the National Police of Ukraine model of intelligence-led policing (Movchan, 2018). In the monograph "Organizational and legal support of analytical work in the system of the Ministry of Internal Affairs of Ukraine (law enforcement and security aspects)" Professor O.Ye. Korystin examines the fundamental rights, principles, and content of basic elements in the system of analytical intelligence (Korystin et al., 2019).

To fully disclose the question of what function criminal analysis plays in the activities of various modern models of policing, as well as how exactly criminal analysis can be used in each of these models, we present several of their classifications. And here it should be noted that the following models do not have clear boundaries, as each of them has different strategic goals, strengths and weaknesses and can complement others and be used simultaneously. Thus, researchers in the methodology of law enforcement reveal five models of policing (Bell and Congram, 2013; OSCE Guidebook Intelligence-Led Policing, 2017; Korystin et al., 2019): Traditional Policing; Community Policing or Community-oriented Policing; Problem-Oriented Policing (POP); Computer Statistical Model (CompStat); Intelligence Led Policing (ILP). 
In its training materials, the International Association of Criminal Analysts (IACA) in describing the terminology, concepts and processes of criminal analysis provides the following classification of police (law enforcement) business models (Bruce et al., 2004): law enforcement activities based on operational data; law enforcement activities based on forecasts; Data-Driven Policing (DDACTS); Accountability model; law enforcement activities focused on the needs of communities; Problem-Oriented Policing (POP); prevention of serious crimes by concentrating the work of the police in places of concentration of minor offenses (model "Broken Windows"); Crime Prevention Through Environmental Design (CPTED); centralized and decentralized models.

There are other classifications of policing models given by both national experts and international organizations and scholars, which have slightly different names but are similar in content. Therefore, we do not set the task to distinguish between different concepts in form and the same content, as this will go beyond our study, so some models of policing will have different names.

\section{Materials and Methods}

The study was conducted on the example of the organization of professional activities of police officers of the Department of Criminal Analysis of the National Police of Ukraine, as well as the implementation of the educational process in higher education institutions with specific training conditions that train police officers. The tools used included analysis of relevant theoretical and methodological sources, as well as generalization of experience in managing the educational process as Head of the Department of Cybersecurity and Information Support and Head of Research Laboratory on Criminal Analysis, Head of Forensics, Head of Department of Police Administration of Odessa State University cases on preparation of educational materials and teaching disciplines: "Information technologies", "Criminal analysis", "Information support of professional activity", "Information-analytical support of law enforcement activity", "Criminalistics" to applicants for higher education. And considering the experience gained during the accreditation of the educational (professional) program "Criminal Analysis" of the second level of higher education, Master's degree in 124 "System Analysis" in the field of knowledge 12 "Information Technology".

To achieve this goal, a number of methods were used, namely: theoretical - for the study and analysis of official documentation, scientific and methodological and educational literature, generalization of information to determine the theoretical and methodological foundations of the study; logical analysis - to formulate the basic concepts and classification; 
concrete-historical - to demonstrate the dynamics of the development of the function of criminal analysis in different models of policing; dialectics - to establish the content and features of the constituent elements of the implementation and application of criminal analysis in policing; empirical methods - to summarize practical experience, observation and discussion.

\section{Results and Discussion}

Traditional policing is the best-known model of policing and remains the standard style of law enforcement. This applies to the reactive and incidental style in which police officers respond to crime and provide services or respond accordingly. Answering calls, receiving complaints, patrolling public places, creating the appearance of a police presence, and uncovering crimes that have occurred in the past or are only being committed are the essence of traditional policing. Because the traditional policing model views security issues and public safety as a police task, community policing focuses on the partnership between the police and the public, actively addressing security issues (OSCE Guidebook IntelligenceLed Policing, 2017).

The use of criminal analysis is carried out mainly in combating organized crime, especially economic, transnational crime, and cybercrime. Thus, today the traditional model of policing faces the fight against modern dangers and threats with increasing mobility and migration, rapid technological and communication changes, free movement of goods and services and growing income inequality. In addition, violent extremism and radicalization leading to terrorism, as well as terrorist acts in recent years, emphasize the need to share, integrate and centrally analyze relevant data and information (operational materials) at all levels in accordance with national legislation, international human rights standards and OSCE commitments. Therefore, the most modern, promising and most integrated in various models of policing is the model of law enforcement based on operational data (model of policing based on operational data and information), or a more modern and meaningful definition of this activity policing, guided by Intelligence Led Policing (ILP).

Intelligence Led Policing is an organizational model and management philosophy in which criminal analysis and criminal intelligence are key tools in achieving a goal by implementing an objective and effective countermeasure decision-making mechanism and preventing crime through strategic management and effective law enforcement, techniques aimed at neutralizing particularly dangerous crimes for society (Kardashevskyi et al., 2019; Allalyev, 2019).

The model of policing based on operational data and information is designed in response to these growing problems, based on and with the 
help of which it is possible to reorient law enforcement activities from the traditional response to anticipation. It has proven to be an effective tool for combating organized crime, more rational use of resources and targeted identification and solution of priority tasks. A proactive and forward-looking approach helps to prevent, reduce, and eliminate crime. A key element in the model is the systematic collection and analysis of information and data related to the prevention, reduction, prevention, and elimination of crime, which is the development of operational data. On this basis, sound and promising policy and management decisions can be made and resources allocated to the most pressing security issues, threats, types of crime and criminals.

Thus, criminal analysis plays an important role in this model, helping to bring critical information to the attention of decision-makers so that they can properly dispose of their forces and means. Analysts in the law enforcement environment work with a variety of data based on operational data, which is systematically and quickly synthesized into useful information for operational and investigative units. Also, the actions of analysts are aimed at anticipating, stopping, and deterring criminal activity. Analyticaldriven policing is increasingly being used to strengthen socially oriented policing by providing specific processes, communication procedures, and governance structures for the collection, analysis, and dissemination of data and information.

Next, we will consider a socially oriented model of policing, which aims to strengthen trust and strengthen communication between the police and the public, conditionally includes such law enforcement models as: law enforcement activities focused on the needs of communities; law enforcement activity, which is focused on certain issues. Although these models are intertwined, they are not identical. Community-oriented law enforcement is a broader organizational philosophy that incorporates the principles of community-based law enforcement and provides for the development of external partnerships with community stakeholders. Community policing programs include the creation of community forums involving representatives of various community groups and institutions, where security issues are discussed and addressed, including offenses and individual crimes in the region.

During problem-oriented policing, identification and analysis of the "problem" is carried out, which is the focus of police work, and not a specific crime, case, challenge, or incident. In this model, special attention is paid to the problem of crime and security in general. The police are actively developing preventive strategies, in an attempt to solve the problem, rather than simply responding to its harmful effects (OSCE Guidebook Intelligence-Led Policing, 2017). 
Criminal analysis plays an integral role in community-based law enforcement - it is a source of information needed for better understanding of the various community problems that arise in communities. From an operational point of view and depending on the level of technical equipment, criminal analysis is a source of statistics on crime and public disorder, which can be used to interpret data at certain geographical levels, such as census districts, groups of census districts, neighborhoods, street sections that need increased attention from the police. Criminal analysts may recommend organizing police meetings with a specific community, during which the police can visually demonstrate information about the criminal situation in the area and provide additional information on police actions in the specified criminogenic situation (Bruce et al., 2004).

Criminal analysis in problem-oriented law enforcement addresses common crime issues, response measures and tools used in practice, such as graffiti, burglary, forgery of prescriptions, car theft and car theft in parking lots, teenage hooliganism in public. The problem considered by the analyst is medium-term, so the information analysis phase is crucial before acting. Because solving a problem in one area, such as increasing patrol routes, can lead to crime moving to another area or a return to the problem after the transfer of police resources to another part of the city. As part of a problem-oriented law enforcement model, specific ways to address a range of different police issues arise through careful and detailed analysis of the causes of such problems, stakeholders, and local characteristics. The model prevents the commission of serious crimes by concentrating the work of the police in places of concentration of minor offenses related to antisocial behavior, violation of public order (model "Broken Windows / Broken Windows").

The role of criminal analysis in the "broken windows" model is to focus on minor incidents of public disorder that can lead to an increase in organized crime. Minor offenses include graffiti, vandalism, antisocial behavior, and drug possession. Police efforts include working more closely with the community to disrupt public order, as well as ensuring greater community participation in the proper maintenance of public facilities and private property and planning a set of measures to prevent the spread of criminal activity and its spread in the territory of abandoned households.

Crime Prevention Model: Crime Prevention Through Environmental Design (CPTED). This model focuses on managing physical planning and the use of a man-made environment to reduce crime and fear of crime, as well as improve quality of life. The elements of the model are access control in the form of closed entrances, surveillance in the form of video surveillance cameras, territorial delimitation in the form of fencing of certain objects and structures (Movchan et al., 2018). 
The function of criminal analysis in the crime prevention model by changing the surrounding infrastructure is not to study where crimes take place or who commits them, but rather to consider the following questions: "what?" and "why?". That is, why do crimes happen in one place and not in another? What elements of the environment contribute to attracting criminal activity? What changes can be made in the immediate and environment to reduce violations of public order. As for the technologies that an analyst can use, it is $3 \mathrm{D}$ mapping that dynamically imagines the crime rate from a multidimensional point of view (Rengert et al., 2001).

The computer statistical policing model or "comparing statistics" (CompStat) is a management system that develops a model in which minor crimes are an element in reducing more serious ones. As part of a performance management system that includes analysis of data on crime and public disorder, strategic tools, and a clear accountability structure (Wakefield and Fleming, 2009). The model emphasizes the dependence on accurate and timely analysis to identify patterns of crime and problems with the subsequent rapid allocation of personnel and resources to take targeted response measures.

Criminal analysis is critical to the CompStat model because it depends heavily on accurate and timely statistics and information. Although the emphasis on statistics is detrimental to the proactive component of criminal analysis and problem solving, the CompStat model helps police officers keep pace with the most pressing issues of crime and disorder, which are assessed through geospatial analysis.

It should be noted that what is the unit of criminal analysis of law enforcement agencies - centralized or decentralized, affects the quantity, quality and volume of analytical products needed by other police units. If the unit is centralized, then all analysts are gathered in one department, usually located in the central office of law enforcement, and all requests pass through this department. In the case of a decentralized unit of criminal analysis, analysts are based in the relevant territorial units or units in activity to which they are assigned.

Properties that are inherent in a centralized unit of criminal analysis: located in a clearly defined place; higher level; regular interaction between the analyst and the command and administrative staff of the police; ease of gaining new knowledge about technology and modern software; working together, analysts can share knowledge from different fields and acquire additional skills; there will be no duplication of work. Instead, the decentralized model provides for the appointment of analysts to various units in the law enforcement agency, which provides the necessary analytical support. The decentralized model is usually used in large units, divided by territory. Analysts in the decentralized model are fully aware of the affairs of their units, including types of crime, demographics, hotspots and more. 


\section{Conclusion}

The study presents some of the most common classifications of police models today, as well as reveals the functional features of criminal analysis in each of these models. Thus, in the plane of normative uncertainty of the basic concepts of information-analytical activity, such as "analytical work", "analytical activity", "analytical document", "criminal analyst", this activity does not cease to exist in the professional activity of law enforcement agencies. Given the modern informatization of all processes in society, the traditional model of policing can no longer provide a high level of public safety, especially against the encroachments of stable organized groups, so it is necessary to introduce a relatively new model of policing, guided by analytical intelligence, a key element of which is systematic collection and analysis of information and data related to the prevention, reduction, prevention, and elimination of crime.

As for the model of computer statistical policing, it is based on the analysis of statistics of crimes committed at the local level and the development of early response measures. It should be noted that Compstat focuses mainly on street and serial crimes with short-term accountability in the process of solving new criminal challenges, and the model of policing led by analytical intelligence includes a long-term strategic component that can be applied in operations to combat transnational organized crime, that is Compstat focuses on crime, and ILP - on the identification of threats.

When considering the socially oriented model of policing, which aims to strengthen trust and strengthen communication between the police and the public, it was found that it includes such law enforcement models as: law enforcement focused on community needs and law enforcement activities focused on specific issues. Within the socially oriented model of policing, specific ways to solve various problems are carried out by careful and detailed analysis of the causes of such problems, stakeholders, and characteristics of the area, as well as prevention of serious crimes by concentrating police work in places of concentration of minor offenses (model "Broken windows"). All these policing models do not have clear boundaries, as each has different strategic goals, strengths and weaknesses and can complement and be used simultaneously. The materials presented in the article will be useful for acquaintance and study by students, cadets, graduate students, associate professors, teachers, judicial and law enforcement officers.

\section{Acknowledgements}

The study was conducted within the framework of Scientific research work No. 0116Uo06767 "Legal and administrative principles of cybercrime" of the Department of Cyber Security and Information Assurance, Faculty of Training for Criminal Police of Odessa State University of Internal Affairs. 


\section{Bibliographic References}

ALLALYEV, Ruslan. 2019. "Religious origins of the rule of law conception in the United States” In: Amazonia Investiga. Vol. 7, No. 14, pp. 212-217.

BELL, Peter; CONGRAM, Mitchell. 2013. "Intelligence-led policing (ILP) as a strategic planning resource in the fight against transnational organized crime (TOC)" In: International Journal of Business and Commerce. Vol. 2, No. 12, pp. 15-28.

BELSKYI, Konstantin Stepanovich. 2004. Police law. "Delo i Servis”. Moscow, Russia.

BRUCE, Christopher; HICK, Steven; COOPER, Julie. 2004. Exploring crime analysis: Readings on essential skills. BookSurge Publishing. Charleston, USA.

FOSDICK, Raymond. 1916. "The modus operandi system in the detection of criminals" In: Journal of Criminal Law and Criminology. Vol. 6, No. 4, pp. 560-570.

ISMAILOV, Karen. 2019. "Peculiarities of human rights and freedom while applying intelligence-led policing (ILP)" In: Scientific Bulletin of the Dnipropetrovsk State University of Internal Affairs. Vol. 1, pp. 36-37.

KARDASHEVSKYI, Yuriy Romanovych; KORYSTIN, Oleksandr Yevheniyovych; PARUBOCHYI, Ivan Volodymyrovych; DOLIA, Lyudmyla Mykolayivna; BOIKO, Ivan Volodymyrovych; SVYRYDJUK, Nazar Petrovych, BULYCHEV, Anatoliy Oleksandrovych; TSYGANOV, Oleh Hryhorovych; KOLLER, Yurii Serhiyovych; BOCHEK, Oksana Ivanivna. 2019. Organizational and legal support of analytical work in the system of the Ministry of Internal Affairs of Ukraine (law enforcement and security aspects). Helvetica Publishing House. Kherson, Ukraine.

KORYSTIN, Oleksandr Yevheniyovych; ALBUL, Serhiy Volodymyrovych; HOLOSTENKO, Andriy Volodymyrovych; ZAIETS, Oksana Mykolayivna; ISMAILOV, Karen Yuriiovych; TETERIATNYK, Hryhoriy Kostyantynovych; HORBANOV, Ivan Mykhaylovych. 2016. Fundamentals of criminal analysis. ODUVS. Odesa, Ukraine.

KORYSTIN, Oleksandr Yevheniyovych; PEFTIIEV, Denys Olehovych; NEKRASOV, Valeriy Andriyovych. 2019. Police chief's handbook: Intelligence-driven policing. Lyudmila Publishing House. Kyiv, Ukraine.

MOVCHAN, Anatoliy Vasylovych. 2018. "Current problems of implementation in the bodies of the National Police of Ukraine of the model of policing guided by analytics" In: Socio-Legal Studies. Vol. 1, pp. 17-22. 
426 Maksym V. Kornüenko, Valentyna V. Horoshko, Igor M. Gorbanov y Karen Yu. Ismailov

ORDER OF THE CABINET OF MINISTERS OF UKRAINE. 2017. On approval of the Strategy for the development of the system bodies of the Ministry of Internal Affairs for the period up to 2020, No. 1023-p. Available online. In: $\quad$ https://zakon3.rada.gov.ua/laws/show/1023-2017-\%D1\%80/. Consultation date: 20/06/2020.

OSCE GUIDEBOOK INTELLIGENCE-LED POLICING. 2017. Available online. In: https://www.osce.org/files/f/documents/d/3/327476.pdf. Consultation date: 18/06/2020.

PRONEVICH, Oleksiy Stanislavovych. 2009. "Police activity as a type of public administration activity” In: Law Forum. Vol. 2, pp. 350-356.

RENGERT, George; HENDERSON, Kristin; MATTSON, Mark. 2001. Campus security: Situational crime preventing in high-density environments. Criminal Justice Press. Monsey, USA.

SHADRIN, Valentyn Mykhaylovych. 2003. "Policing as an object of study (historical and legal aspect)" In: CSU Bulletin. Vol. 1, pp. 111-117.

THE DECLARATION ON THE POLICE. 1979. Resolution of the Parliamentary Assembly of the Council of Europe, No. 690. Available online. In: https://zakon.rada.gov.ua/laws/show/994_803. Consultation date: 12/06/2020.

WAKEFIELD, Alison; FLEMING, Jenny. 2009. The SAGE dictionary of policing. Sage Publications. Thousand Oaks, USA. 

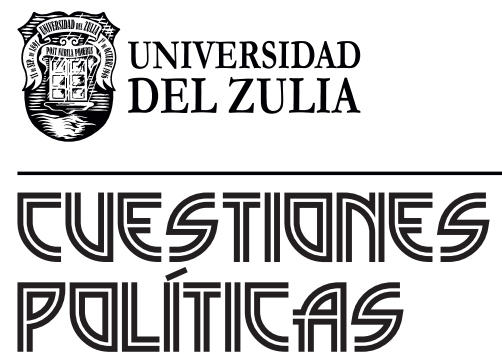

Vol.39 No 68

Esta revista fue editada en formato digital y publicada en enero de 2021, por el Fondo Editorial Serbiluz, Universidad del Zulia. Maracaibo-Venezuela 